\title{
ANALISIS LITERASI KEUANGAN DAN FAKTOR-FAKTOR YANG MEMPENGARUHINYA
}

(Survey pada Pelaku Usaha Mikro, Kecil, Dan Menengah di Kota Bandung)

\author{
Suryanto ${ }^{1}$ Mas Rasmini ${ }^{2}$ \\ ${ }^{1,2}$ Departemen Adminsitrasi Bisnis, Universitas Padjadjaran \\ email : ${ }^{1}$ suryanto@ unpad.ac.id; ${ }^{2}$ mas.rasmini@unpad.ac.id
}

\begin{abstract}
This study aims to analyze financial literacy and find out the factors that influence the financial literacy of micro, small and medium enterprises (MSMEs) in the city of Bandung. This study uses a quantitative approach to the type of verification research. Primary data is obtained through the distribution of questionnaires to MSMEs players in the city of Bandung. The sampling technique uses proportional random sampling with a sample size of 30 respondents. Other data is obtained through library observation and study. The analysis technique used is multiple linear regression. The results showed that the financial literacy of SMEs in the city of Bandung was in the medium category. There are several factors that simultaneously influence financial literacy, namely age, formal education level, and business income. While partially only the formal education level and business income that influences the level of financial literacy. While age does not have an effect on the level of financial literacy.
\end{abstract}

Keywords: age, education level, business income, financial literacy

\begin{abstract}
Abstrak
Penelitian ini bertujuan untuk menganalisis literasi keuangan dan mengetahui faktor-faktor yang mempengaruhi literasi keuangan pelaku usaha mikro, kecil dan menengah (UMKM) di Kota Bandung. Penelitian ini menggunakan pendekatan kuantitatif dengan jenis penelitian verifikatif. Data primer diperoleh melalui penyebaran kuesioner kepada pelaku UMKM di Kota Bandung. Teknik pengambilan sampel menggunakan proporsional random sampling dengan ukuran sampel sebanyak 30 responden. Data lainnya didapatkan melalui observasi dan studi kepustakaan. Adapun teknik analisis yang digunakan dengan regresi linear berganda. Hasil penelitian menunjukkan bahwa literasi keuangan pelaku UMKM di Kota Bandung berada dalam kategori sedang. Ada beberapa faktor yang secara simultan berpengaruh terhadap literasi keuangan yaitu usia, tingkat pendidikan formal, dan pendapatan usaha. Sedangkan secara parsial hanya tingkat pendidikan formal dan pendapatan usaha yang berpengaruh terhadap tingkat literasi keuangan. Sedangkan usia tidak tidak berpengaruh terhadap tingkat literasi keuangan.
\end{abstract}

Kata Kunci: usia, tingkat pendidikan, pendapatan usaha, literasi keuangan 


\section{PENDAHULUAN}

Usaha Mikro, Kecil, dan Menengah (UMKM) memiliki dominasi peran yang besar pada perekonomian di Indonesia. Berdasarkan data dari Kementrian Koperasi dan UMKM, pada akhir tahun 2014, terdapat sekitar 57,9 juta pelaku UMKM, dengan kontribusi PDB sebesar 58,92\% dan kontribusi dalam penyerapan tenaga kerja sebesar 97,30\%. (Sari dan Sari, 2014). Agar peran pelaku UMKM terus dapat bertahan bahkan dapat meningkat, diperlukan pengetahuan dan literasi keuangan yang cukup. Dengan penguasaan pengetahuan dan literasi keuangan yang cukup mereka akan mampu mengelola keuangan dengan seefisien mungkin. Para pelaku UMKM menurut Hilgert, dkk (2003) serta Cude, dkk (2006) perlu mengetahui bagaimana mengelola keuangan serta bagaimana teknik berinvestasi.

Kondisi ekonomi saat ini menuntut pelaku UMKM untuk membuat keputusankeputusan mengenai keuangan yang lebih cepat namun lebih kompleks. Kurangnya literasi keuangan menurut Kardinal (2015) dapat mengakibatkan rendahnya akses ke lembaga keuangan yang akan berdampak pada kesalahan pengalokasian kekayaan dan pendapatan. Literasi keuangan yang rendah juga berdampak kepada terbatasnya akses sumber permodalan yang hanya mengandalkan perbankan. Sementara produkproduk dari lembaga pembiayaan yang lainnya

kurang

dikenal

(www.antaranews.com, 2016).

Permasalahan lainnya dengan rendahnya literasi keuangan bagi pelaku UMKM akan berdampak pada perkembangan usaha yang dijalankan, bahkan akan berdampak pada perekonomian secara nasional. Menurut Hadad (dalam Riski dan Rini, 2015) perekonomian nasional tidak akan mudah tergoyahkan atau terimbas berbagai krisis keuangan dunia jika masyarakat memahami sistem keuangan.

Kenyataannya, menurut Yuliana (2013) tidak semua orang terutama di Indonesia memiliki pengetahuan keuangan yang cukup atau dapat dikatakan well literate. Penelitian yang dilakukan oleh Otoritas Jasa Keuangan/OJK (2016) menyimpulkan bahwa tingkat literasi keuangan masyarakat Indonesia masih berada pada kategori rendah. Kota Bandung yang dikenal sebagai kota kreatif diharapkan para pelaku UMKM-nya memiliki pemahaman pengetahuan literasi keuangan yang terus meningkat.

Berdasarkan penelitian yang dilakukan oleh Riski dan Rini (2015) bahwa tingkat literasi keuangan pelaku UMKM di Kota Tegal berada pada rata-rata 11,79 pada skala 0 - 20 hampir mendekatai rendah. Sementara penelitian Anggraeni (2015) menunjukkan bahwa pelaku UMKM di Depok hanya mampu menjawab $43,75 \%$ pertanyaan mengenai literasi keuangan dengan benar dan 
berpengaruh pada kemampuan pengelolaan keuangan. Rendahnya tingkat literasi keuangan menurut Gupta dan Kaur (2014) membuat adanya hambatan pengusaha mikro dalam menggunakan sumber keuangan dengan baik dan mempengaruhi pendapatan dan pertumbuhan usahanya.

$\begin{array}{rrr}\text { Berkembangnya } & \text { pelaku usaha } \\ \text { sebaiknya diikuti juga dengan }\end{array}$
berkembangnya pemahaman mereka terhadap literasi keuangan. Menurut Hapsari (2102) agar pemahaman pengetahuan keuangan mereka meningkat perlu dicari faktor-faktor yang dapat mempengaruhi literasi keuangan. Ada beberapa penelitian terdahulu mengenai faktor-faktor yang dapat mempengatuhi literasi keuangan yang telah dilakukan baik di Indonesia maupun di negara lain.

Penelitian yang dilakukan Worthington (2006) menyebutkan bahwa jenis kelamin, usia, tingkat pendidikan, pendapatan, etnis atau ras, dan pekerjaan adalah faktor yang mempengaruhi literasi keuangan. Peneliti lainnya adalah Mandell (2008) yang menyimpulkan bahwa salah satu fakro yang mempengaruhi literasi keuangan adalah demografi yang merupakan gambaran mengenai latar belakang seseorang.

Kemudian penelitian berikutnya dilakukan oleh Mahdzan dan Tabiani (2013) yang menemukan bahwa faktor demografi yang berpengaruh pada literasi keuangan adalah umur, jenis kelamin, tingkat pendidikan, jumlah anak, status menikah dan pengalaman bekerja. Namun, hasil penelitian yang berbeda dilakukan Suachi (2013) yang menyatakan bahwa jenis kelamin tidak memiliki pengaruh terhadap literasi keuangan. Menurut Suachi (2013) yang menyebabkan literasi keuangan lebih tinggi adalah pendidikan. Sedangkan penelitian yang dilakukan Riski dan Rini (2015) menyatakan bahawa faktor tingkat pendidikan merupakan faktor yang dapat mempengaruhi literasi keuangan.

Berdasarkan hasil penelitian sebelumnya adanya inkonsistensi di dalam hasil penelitian mengenai faktor-faktor yang dapat mempengaruhi literasi keuangan. Peneliti tertarik untuk melakukan penelitian kembali mengenai faktor-faktor tersebut, antara lain usia, tingkat pendidikan dan pendapatan usaha.

\section{Tinjauan Pustaka}

\subsection{Literasi Keuangan}

Literasi keuangan banyak didefinisikan oleh berbagai penelitian dan lembaga secara berbeda. Tidak ada standar yang universal mengenai definisi literasi keuangan. Chen dan Volpe (1998) mengatakan financial literacy can be defined as an individual's ability to obtain, understand and evaluate the relevant information necessary to make decisions with 
an awareness of the likely financial consequences. Sementara Lusardi \& Mitchaell (2007) menjelaskan literasi keuangan dapat diartikan sebagai pengetahuan keuangan yang memiliki tujuan untuk mencapai kesejahteraan.

Kemudian Orton (2007) memperjelas dengan menyatakan bahwa literasi keuangan menjadi hal yang tidak terpisahkan dalam kehidupan seseorang karena literasi keuangan merupakan alat yang berguna untuk membuat keputusan keuangan yang terinformasi. Menurut Khrisna (2010) literasi keuangan terjadi manakala seorang individu memiliki sekumpulan keahlian dan kemampuan yang membuat orang tersebut mampu memanfaatkan sumber daya yang ada untuk mencapai tujuan.

Definisi lainnya menurut Kharchenko (2011) bahwa literasi keuangan adalah sebuah keterampilan numerik yang diperlukan dan pemahaman terhadap konsep dasar ekonomi yang dibutuhkan untuk mendidik dalam keputusan menyimpan dan meminjam. Lebih lanjut Mendari \& Kewal (2014) menjelaskan bahwa literasi keuangan merupakan kebutuhan dasar bagi setiap orang agar terhindar dari masalah keuangan.

Chen dan Volpe (1998) serta Mendari \& Kewal (2014) menyatakan bahwa literasi keuangan dibagi menjadi 4 aspek, yaitu: general pesonal finance knowledge, saving and borrowing, insurance, dan investment. Sementara Oseifuah (2010) dan Wise (2013) memyebutkan ada beberapa elemen kunci dari kemampuan dan pengetahuan literasi keuangan, yaitu: (1) pengetahuan matematis dan pengetahuan standar seperti angka dasar dan kemampuan dalam memahami; pemahaman keuangan mengenai sifat dasar dan bentuk uang, bagaimana uang digunakan dan konsekuensi dari keputusan konsumsi; (3) Kompetensi keuangan seperti memahami ciriciri utama dari layanan dasar keuangan, sikap dalam menggunakan uang dan tabungan, memahami pencatatan keuangan dan menyadari pentingnya membaca dan memeliharanya; (4) Sadar akan risiko-risiko yang berhubungan dengan produk keuangan, dan memahami hubungan antara risiko dan pendapatan; dan (5) Tanggung jawab keuangan, yaitu kemampuan untuk membuat keputusan yang tepat mengenai isu-isu keuangan, mengetahui hak dan tanggung jawab konsumen, kemampuan, dan kepercayaan untuk mencari bantuan ketika sesuatu berjalan tidak semestinya.

Sementara Widiyati

mengembangkan 15 indikator literasi keuangan yang telah disesuaikan dengan kondisi di Indonesia, yaitu: (1) mencari pilihan-pilihan dalam berkarir; (2) memahami faktor-faktor yang mempengaruhi gaji bersih; (3) mengenal sumber-sumber pendapatan; (4) 
menjelaskan bagaimana mencapai kesejahreraan dan memenuhi tujuan keuangan; (5) memahami anggaran menabung; (6) memhami asuransi; (7) menganalisis risiko, pengemabliam dan likuiditas; (8) mengevaluasi alternatifalternatif investasi; (9) menganalisis pengaruh pajak dan inflasi terhadap hasil investasi; (10) menganalisis keuntungan dan kerugian berhutang; (11) menjelaskan tujuan dari rekam jejak kredit dan mengenail hak-hak debitur; (12) mendeskripsikan cara-cara menghindar atau memperbaiki masalah hutang; (13) mengetahui hukum dasar perlindungan konsumen dalam kredit dan hutang; (14) mampu membuat pencatatan keuangan; dan (15) memahami laporan neraca, laba rugi dan arus kas.

Ada dua pendekatan untuk mengukur literasi keuangan menurut Kharchenko (2011), yaitu: self assessment dan objective measure like test score. Literasi keuangan dapat digolongkan ke dalam beberapa kategori. Otoritas Jasa Keuangan (2016) menggolongkan tingkat literasi keuangan dalam 4 (empat) kategori, yaitu:

1) Well Literate: memiliki pemahaman dan keyakinan tentang lembaga jasa keuangan serta produk dan jasa keuangan, termasuk fitur, manfaat dan risiko, hak dan kewajiban terkait produk dan jasa keuangan, serta memiliki keterampilan dalam menggunakan produk dan jasa keuangan.

2) Sufficient Literate: memiliki pemahaman dan keyakinan tentang lembaga jasa keuangan serta produk dan jasa keuangan, termasuk fitur, manfaat dan risiko, hak dan kewajiban terkait produk dan jasa keuangan.

3) Less Literate: hanya memiliki pemahaman tentang lembaga jasa keuangan, produk dan jasa keuangan.

4) Not Literate: tidak memiliki pemahaman dan keyakinan tentang lembaga jasa keuangan serta produk dan jasa keuangan, serta tidak memiliki keterampilan dalam menggunakan produk dan jasa keuangan.

\subsection{Faktor yang Mempengaruhi Literasi Keuangan}

Kemampuan dan pengetahuan seseorang mengenai keuangan pasti berbeda pada tiap individu dan terdapat banyak faktor yang dapat mempengaruhi literasi keuangan. Menurut Ansong \& Gyensare (2012) faktor yang mempengaruhi literasi keuangan, antara lain: usia, pengelaman kerja, pendidikan ibu dan jurusan saat kuliah. Riski dan Rini (2015), menjelaskan bahwa faktor yang mempengaruhi literasi keuangan adalah gender dan tingkat pendidikan. Sedangkan Nababan, dkk (2013) menyatakan faktor yang mempengaruhi literasi keuangan adalah jenis 
kelamin, indeks prestasi kumulatif, stambuk, dan residence.

Faktor lainnya yang mempengaruhi literasi keuangan menurut Andrew dan Linawati (2014), antara lain: jenis kelamin, dan tingkat pendapatan. Menurut Sucuachi (2013), tingkat pendidikan akan mempengaruhi tingkat literasi keuangan. Sedangkan Worthington (2006) menggunakan jenis kelamin, usia, etnis atau ras, pekerjaan, tingkat pendidikan dan pendapatan sebagai faktor yang mempengaruhi literasi keuangan.

Menurut Otoritas Jasa Keuangan (2016) faktor-faktor yang mempengaruhi tingkat literasi keuangan adalah jenis kelamin, tingkat pendidikan, dan tingkat pendapatan. Pernyataan yang tidak jauh berbeda diungkapkan oleh The Australia and New Zealand Banking Group Limited (dalam ANZ, 2015) yang menyebutkan faktor yang mempengaruhi literasi keuangan adalah usia, pengetahuan keuangan dan numerik sikap keuangan, pendapatan rumah tangga serta pendidikan dan jabatan.

\section{Metode Penelitian}

Jenis penelitian yang digunakan dalam penelitian ini adalah penelitian eksplanatori dengan pendekatan kuantitatif. Data primer diambil dari pelaku UMKM di Kota Bandung dengan ukuran sampel 30 orang. Sedangkan data sekunder diperoleh dari studi kepustakaan yang berupa keterangan atau fakta dengan mempelajari buku, jurnal, dan artikel yang berkaitan dengan permasalahan yang diteliti.

Sebelum kuisioner digunakan sebagai instrumen penelitian, terlebih dahulu dilakukan uji coba instrumen penelitian dengan uji validitas dan reliabilitas. Adapun pengkategorikan literasi keuangan berdasarkan penelitian yang dilakukan oleh Chen dan Volpe (1998) berdasarkan jumlah skor jawaban yang benar dari responden.

Tabel 1. Kategori Literasi Keuangan

\begin{tabular}{|c|c|}
\hline $\begin{array}{c}\text { Persentase jawaban } \\
\text { benar }\end{array}$ & Kategori \\
\hline $\mathrm{X}<60 \%$ & Rendah \\
\hline $60 \% \leq \mathrm{X}<80 \%$ & Sedang \\
\hline $\mathrm{X} \geq 80 \%$ & Tinggi \\
\hline \multicolumn{2}{|c|}{ Sumber: Chen and Volpe (1998) }
\end{tabular}

Untuk mencari fakttor-faktor yang mempangaruhi literasi keuangan digunakan analisis regresi linier berganda dengan menggunakan program komputer (software) SPSS versi 23.0. Sedangkan untuk menguji hipotesis digunakan nuji statistik $\mathrm{F}$ dan uji statistik t. 
4. Hasil dan Pembahasan Penelitian

\subsection{Hasil Penelitian}

\section{a. Literasi Keuangan Pelaku UMKM di}

\section{Kota Bandung}

Literasi keuangan dapat diartikan sebagai pengetahuan tentang keadaan keuangan dan keterampilan pengunaannya dalam pengambilan keputusan tentang keuangan. Literasi keuangan pada pelaku UMKM di Kota Bandung diukur melalui 16 pertanyaan mengenai pengetahuan umum keuangan, tabungan dan hutang, asuransi, serta investasi.

Berikut adalah hasil pengukuran terhadap literasi keuangan secara keseluruhan.

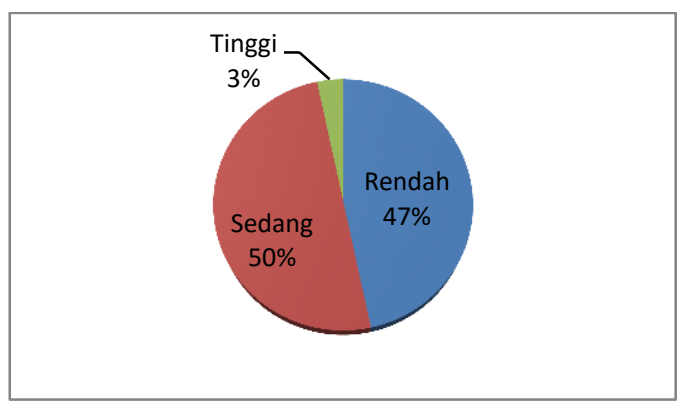

Gambar 1. Tingkat Literasi Keuangan Pelaku UMKM di Kota Bandung

Secara rata-rata pelaku UMKM di Kota Bandung memiliki literasi keuangan sebesar $60,83 \%$ dan berada dalam kategori sedang. Sedangkan secara lebih rinci literasi keuangan pelaku UMKM hanya 3\% yang tinggi, 47\% rendah, dan 50\% yang memiliki tingkat literasi keuangan sedang.
Hasil pengukuran rata-rata literasi keuangan menunjukkan pelaku UMKM masih jauh dari optimum, bahkan mendekati kategori tingkat literasi keuangan rendah. Hal ini menunjukkan bahwa tingkat literasi keuangan pelaku UMKM di Kota Bandung masih harus ditingkatkan lagi agar mampu meningkatkan usaha dan kemampuan bersaing.

Literasi keuangan akan berpengaruh pada kemampuan pengelolaan dan pengambilan keputusan keuangan. Salah satu manfaat dari literasi keuangan adalah adanya kesempatan untuk akses ke lembaga keuangan yang lebih besar dan kemampuan pengalokasian dana yang tepat. Tingkat literasi keuangan yang memadai juga berarti pelaku UMKM akan mampu memahami dan mengevaluasi informasi yang relevan dalam mengambil keputusan usaha, serta memahami konsekuensi yang timbul akan keputusannya. Hal ini akan membuat pelaku UMKM berhati-hati dalam mengambil keputusan karena telah mengkalkulasi keuntungan dan risikonya.

Berikut ini adalah analisis literasi keuangn berdasarkan dimensi-dimensinya.

\section{1) Dimensi Pengetahuan Umum \\ Keuangan}

Pengetahuan umum keuangan merupakan pemahaman mengenai konsep keuangan yang berlaku secara umum. 
Pengetahuan ini akan menjadi dasar untuk memahami ilmu keuangan tingkat lanjut. Pengetahuan umum keuangan mencakup pengetahuan keuangan pribadi serta memahami konsep dasar keuangan.

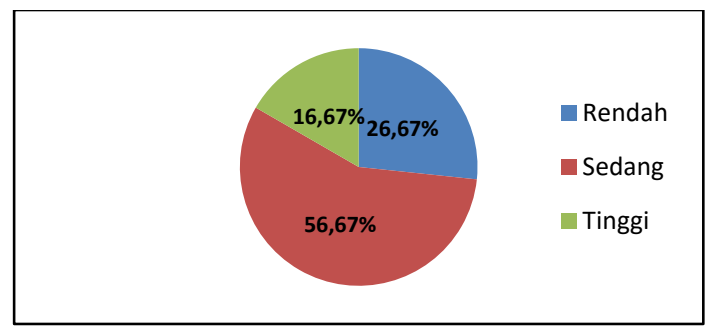

Gambar 2. Tingkat Literasi Keuangan Dimensi

\section{Pengetahuan Umum Keuangan}

Pelaku UMKM di Kota Bandung memiliki literasi keuangan dimensi pengetahuan umum keuangan sebesar 72,5\% atau berada pada tingkat sedang. Secara lebih rinci, sebanyak $26,67 \%$ memiliki pengetahuan umum keuangan yang rendah dan hanya $16,67 \%$ pelaku UMKM yang memiliki pengetahuan umum keuangan yang tinggi. Hampir sebagian pelaku UMKM yaitu $56,67 \%$ memiliki pengetahuan umum keuangan tingkat sedang. Tingkat pengetahuan umum keuangan paling tinggi berada pada pelaku usaha UMKM usia 41-50 tahun, lulusan sarjana, dan memiliki pendapatan usaha antara 21-30 juta rupiah per bulan.

Pelaku UMKM dituntut untuk membuat keputusan yang akan berpengaruh terhadap jalannya bisnis. Pengetahuan umum keuangan yang relatif tinggi dibandingkan aspek dimensi lain disebabkan karena dibutuhkannya pengetahuan umum sebagai dasar pengambilan keputusan-keputusan dalam bisnis tersebut.

\section{2) Dimensi Tabungan dan Hutang}

Dimensi tabungan dan hutang mengukur sejauh mana pemaham pelaku usaha mengenai konsep tabungan dan hutang. Tabungan dan hutang merupakan produk bank yang lekat dengan kehidupan masyarakat. Tabungan adalah pendapatan yang tidak dikonsumsi dan dijadikan dana cadangan atau simpanan yang penarikannya mengikuti syarat tertentu. Hutang atau pinjaman pada penelitian ini akan difokuskan kepada kredit.

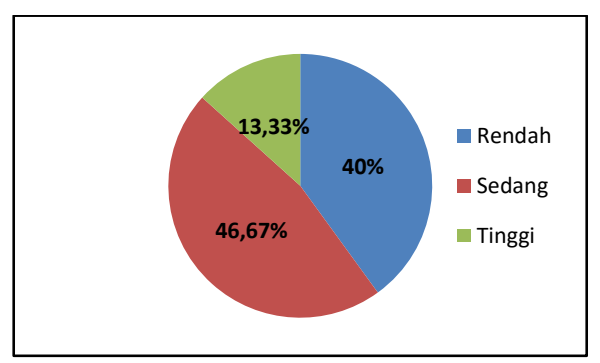

Gambar 3. Tingkat Literasi Keuangan Dimensi Tabungan dan Hutang

Pelaku UMKM di Kota Bandung memiliki literasi keuangan dimensi tabungan dan hutang sebesar 67,50\% atau berada pada tingkat sedang. Secara lebih rinci, sebanyak 40\% pelaku UMKM memiliki tingkat literasi keuangan dimensi tabungan dan hutang yang rendah dan $46,67 \%$ memiliki literasi 
keuangan dimensi tabungan dan hutang sedang, serta hanya $13,33 \%$ memiliki literasi keuangan dimensi tabungan dan hutang yang tinggi. Tingkat literasi keuangan dimensi tabungan dan hutang kategori tinggi paling banyak berada pada pelaku UMKM dengan pendidikan formal jenjang sarjana.

Literasi keuangan dimensi tabungan dan hutang termasuk kategori sedang disebabkan oleh pelaku UMKM yang terbiasa melakukan transaksi yang berkaitan dengan produk perbankan dalam kegiatan usaha sehari-hari. Transaksi tersebut secara tidak langsung akan membuat pelaku UMKM mengetahui informasi mengenai produk perbankan.

\section{3) Dimensi Asuransi}

Asuransi dapat diartikan sebagai persetujuan pihak yang menjamin berjanji pada pihak yang dijamin untuk menerima sejumlah uang premi sebagai pengganti kerugian yang diderita oleh yang dijamin.

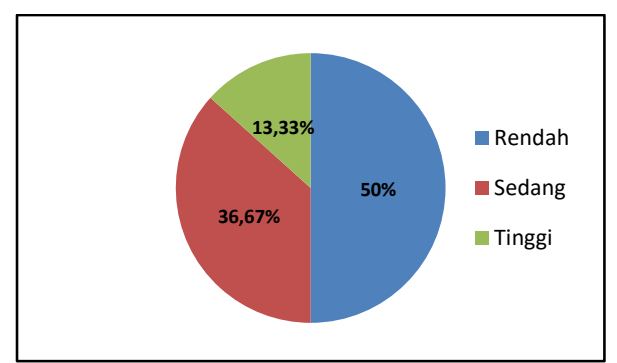

Gambar 4. Tingkat Literasi Keuangan Dimensi Asuransi

Pelaku UMKM di Kota Bandung memiliki literasi keuangan dimensi asuransi sebesar $60,83 \%$ atau berada pada tingkat sedang, cenderung rendah. Secara lebih rinci, sebanyak 50\% pelaku UMKM memiliki tingkat literasi keuangan dimensi asuransi yang rendah dan $36,67 \%$ memiliki literasi keuangan dimensi asuransi sedang, dan hanya 13,33\% memiliki literasi keuangan dimensi asuransi yang tinggi.

Pengetahuan akan asuransi yang masih rendah disebabkan karena asuransi belum dianggap sebagai kebutuhan primer sehingga yang mencari informasi hanyalah yang sudah merasa membutuhkan. Pelaku UMKM yang memiliki asuransi hanya sebesar $26,67 \%$. Literasi keuangan dimensi asuransi cenderung lebih tinggi pada pelaku usaha dengan usia diatas 30 tahun. Sebelum mencapai usia 30, mereka cenderung merasa resiko atas hidup dan usahanya masih rendah.

\section{4) Dimensi Investasi}

Investasi dapat diartikan sebagai cara untuk menyimpan atau menempatkan uang agar bisa bekerja sehingga dapat menghasilkan uang yang lebih banyak. Cara yang sering digunakan seseorang dalam berinvestasi yakni dengan meletakkan uang ke dalam surat berharga termasuk saham, obligasi dan reksa dana, atau dengan membeli real estate. 


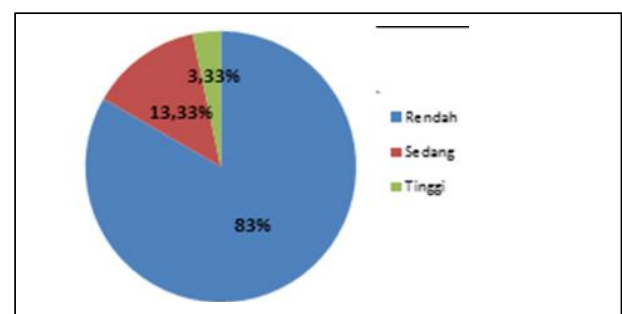

Gambar 5.Tingkat Literasi Keuangan Dimensi Investasi

Pelaku UMKM di Kota Bandung memiliki literasi keuangan dimensi investasi sebesar 42,50\%yang berada pada kategori rendah. Secara lebih rinci, sebanyak $83,33 \%$ pelaku UMKM memiliki tingkat literasi keuangan dimensi investasi yang rendah dan 13,33\% memiliki literasi keuangan dimensi investasi sedang, dan hanya 3,33\% memiliki literasi keuangan dimensi investasi yang tinggi.

Rendahnya literasi mengenai investasi ini didasari oleh orientasi keuangan yang terkait dengan tujuan keuangan. Tujuan keuangan yang dimiliki masih lebih banyak untuk tujuan jangka pendek, misalnya untuk memenuhi kebutuhan hidup sehari-hari.

Pengetahuan mengenai investasi sangat dibutuhkan oleh pelaku UMKM karena investasi dapat dijadikan sebagai sumber pemasukan sampingan selain usaha yang dijalankan. Ketika pelaku UMKM sudah mulai tergiur dengan investasi namun memiliki pengetahuan yang rendah, kesempatan mereka untuk menjadi korban penipuan investasi semakin besar.

\section{b. Faktor-faktor yang Mempengaruhi}

\section{Literasi Keuangan}

Ada beberapa faktor yang mempengaruhi literasi keuangan, tetapi penulis akan menguji 3 (tiga) faktor yang dianggap dominan, yaitu usia, tingkat pendidikan dan pendapatan usaha. Berdasarkan hasil uji asumsi klasik yang telah dilakukan menunjukkan bahwa data yang digunakan dalam model regresi penelitian ini berdistribusi normal, tidak ditemukan adanya multikolinearitas antar variabel bebas, serta tidak terjadi gejala heteroskedastisitas. Dengan demikian, analisis regresi linier berganda dapat digunakan untuk mengetahui pengaruh usia, tingkat pendidikan, dan tingkat pendapatan terhadap literasi keuangan pelaku UMKM di Kota Bandung.

Analisis regresi linier berganda dilakukan untuk mengetahui seberapa besar pengaruh variabel-variabel independen yaitu usia, tingkat pendidikan, serta pendapatan usaha terhadap variabel dependen yaitu literasi keuangan. 
Tabel 2. Hasil Analisis Regresi Linear

\section{Berganda}

\begin{tabular}{|c|c|c|c|c|c|c|}
\hline \multicolumn{7}{|c|}{ Coefficients $^{a}$} \\
\hline & \multirow[t]{2}{*}{ Model } & \multicolumn{2}{|c|}{$\begin{array}{l}\text { Unstandardized } \\
\text { Coefficients }\end{array}$} & \multirow{2}{*}{$\begin{array}{c}\text { Standardized } \\
\text { Coefficients } \\
\text { Beta } \\
\end{array}$} & \multirow[t]{2}{*}{$\mathrm{t}$} & \multirow[t]{2}{*}{ Sig. } \\
\hline & & $\beta$ & Std. Error & & & \\
\hline \multirow[t]{4}{*}{1} & (Constant) & .4604 & .048 & & 9.630 & .000 \\
\hline & Usia & .0002 & .001 & .019 & .131 & .897 \\
\hline & Pendidikan & .0436 & .016 & .468 & 2.776 & .010 \\
\hline & Pendapatan & .0024 & .001 & .352 & 2.188 & .038 \\
\hline
\end{tabular}

Berdasarkan hasil dari Tabel 2, maka diperoleh persamaan regresi linier berganda sebagai berikut:

$$
\begin{gathered}
Y=0,4604+0,0002 X_{1}+0,0436 X_{2}+ \\
0,0024 X_{3}
\end{gathered}
$$

Keterangan

Y : Literasi Keuangan

$\mathrm{X}_{1}$ : Usia

$\mathrm{X}_{2}$ : Tingkat Pendidikan

$\mathrm{X}_{3}$ : Pendapatan Usaha

Dari persamaan regresi linear berganda di atas, dapat diartikan sebagai berikut:

(1). Nilai konstanta sebesar 0,4604, artinya jika usia $\left(X_{1}\right)$, tingkat pendidikan $\left(X_{2}\right)$, dan pendapatan usaha $\left(\mathrm{X}_{3}\right)$ dianggap konstan atau bernilai 0, maka literasi keuangan (Y) adalah sebesar 0,4604 atau $46,04 \%$.

(2). Nilai koefisien $\beta_{1}$ sebesar 0,0002 bernilai positif artinya terjadi hubungan positif antara usia dan literasi keuangan, semakin besar usia maka akan semakin besar literasi keuangan. Setiap peningkatan 1 tahun usia $\left(\mathrm{X}_{1}\right)$ berpengaruh terhadap peningkatan literasi keuangan (Y) sebesar $0,02 \%$ dengan asumsi variabel tingkat pendidikan $\left(\mathrm{X}_{2}\right)$ dan pendapatan usaha $\left(\mathrm{X}_{3}\right)$ dianggap konstan atau bernilai 0 .

(3). Nilai koefisien $\beta_{2}$ sebesar 0,0436 bernilai positif artinya terjadi hubungan positif antara pendidikan dan literasi keuangan, semakin tinggi pendidikan seseorang maka semakin besar literasi keuangan. Setiap peningkatan 1 tingkat pendidikan $\left(\mathrm{X}_{2}\right)$ berpengaruh terhadap peningkatan literasi keuangan (Y) 4,36\% dengan asumsi variabel usia $\left(\mathrm{X}_{1}\right)$ dan pendapatan usaha $\left(\mathrm{X}_{3}\right)$ dianggap konstan atau bernilai 0 .

(4).Nilai koefisien $\beta_{3}$ sebesar 0,0024 bernilai positif artinya terjadi hubungan positif antara pendapatan usaha dan literasi keuangan, semakin tinggi pendapatan usaha seseorang maka semakin besar literasi keuangan. Setiap peningkatan 1 satuan pada pendapatan usaha $\left(\mathrm{X}_{2}\right)$ berpengaruh terhadap peningkatan literasi keuangan (Y) sebesar 0,24\% dengan asumsi variabel usia (X1) dan tingkat pendidikan $\left(\mathrm{X}_{2}\right)$ dianggap konstan atau bernilai 0 .

Analisis koefisien korelasi berganda (R) digunakan untuk mengetahui kuatnya hubungan usia, tingkat pendidikan, dan pendapatan usaha secara bersama-sama dengan literasi keuangan pelaku UMKM di 
Kota Bandung. Sedangkan koefisien determinasi $\left(\mathrm{R}^{2}\right)$ digunakan untuk menganalisis seberapa variabel independen mempengaruhi variabel dependen.

Tabel 3. Hasil Uji Koefisien Korelasi dan

\section{Koefisien Determinasi}

\begin{tabular}{|l|r|r|l|r|}
\hline Model & R & R Square & Adjusted R Square $^{\text {R Summary }}{ }^{\mathbf{b}}$ & $\begin{array}{c}\text { Std. Error of the } \\
\text { Estimate }\end{array}$ \\
\hline 1 & $.732^{\mathrm{a}}$ & .535 & .482 & .0613216 \\
\hline
\end{tabular}
a. Predictors: (Constant), Pendapatan, Usia, Pendidikan
b. Dependent Variable: LitKeu

Nilai koefisien korelasi berganda (R) antara usia, tingkat pendidikan, dan pendapatan usaha dengan literasi keuangan pelaku UMKM di Kota Bandung adalah sebesar 0,732. Hal ini menunjukkan hubungan yang kuat. Sedangkan nilai koefisien determinasi sebesar 0,535 yang berarti bahwa $53,5 \%$ literasi keuangan dapat dijelaskan dan dipengaruhi oleh usia, tingkat pendidikan dan pendapatan usaha. Sisanya sebesar 46,5\% dijelaskan dan dipengaruhi oleh faktor lain di luar penelitian.

Pengujian ini dilakukan untuk mengetahui apakah usia, tingkat pendidikan formal, dan pendapatan usaha $\left(\mathrm{X}_{1,2,3}\right)$ sebagai suatu kesatuan terhadap literasi keuangan (Y) atau menguji pengaruh varibel independen secara simultan terhadap variabel dependen.

\section{Tabel 4. Hasil Uji F}

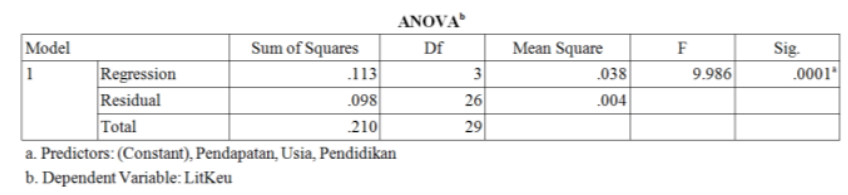

Hasil perhitungan menunjukkan taraf signifikansi sebesar 0,0001 ; di mana angka tersebut lebih kecil dari dari $\alpha$ sebesar 0,05; yang berarti $\mathrm{H}_{11}$ diterima. Sehingga dapat disimpulkan bahwa usia, tingkat pendidikan, dan pendapatan usaha secara simultan berpengaruh terhadap literasi keuangan pelaku UMKM di Kota Bandung.

Pengujian ini dilakukan untuk mengetahui seberapa jauh pengaruh satu variabel independen terhadap variabel dependen (Y) dengan menganggap variabel independen lainnya konstan. Uji parsial dilakukan dengan Uji t. Berdasarkan hasil perhitungan pada Tabel 2, diperoleh hasil pengujian sebagai berikut

1) nilai signifikansi usia $\left(X_{1}\right)$ sebesar 0,897 lebih besar dari 0,05 sehingga $\mathrm{H}_{12}$ ditolak, atau dapat disimpulkan bahwa usia $\left(\mathrm{X}_{1}\right)$ secara parsial tidak berpengaruh terhadap literasi keuangan (Y).

2) nilai signifikansi tingkat pendidikan $\left(X_{2}\right)$ sebesar 0,010. Nilai signifikansi lebih kecil dari 0,05 sehingga $\mathrm{H}_{13}$ diterima, atau dapat disimpulkan bahwa tingkat pendidikan $\left(\mathrm{X}_{2}\right)$ secara parsial berpengaruh terhadap literasi keuangan (Y).

3) nilai signifikansi pendapatan usaha $\left(X_{3}\right)$ sebesar 0,038 lebih kecil dari 0,05 sehingga $\mathrm{H}_{14}$ diterima, atau dapat disimpulkan bahwa pendapatan usaha 
$\left(\mathrm{X}_{3}\right)$ secara parsial berpengaruh terhadap literasi keuangan $(\mathrm{Y})$.

\subsection{Pembahasan Penelitian}

Penelitian ini merupakan studi mengenai pengaruh faktor usia, tingkat pendidikan, dan pendapatan usaha terhadap literasi keuangan pada pelaku UMKM di Kota Bandung. Literasi keuangan diukur melalui indikator pengetahuan umum keuangan, tabungan dan hutang, asuransi, dan investasi.

a. Pengaruh Usia, Tingkat Pendidikan, dan Pendapatan Usaha Secara Simultan terhadap Literasi Keuangan Pelaku UMKM di Kota Bandung

Berdasarkan hasil pengujian bahwa terdapat pengaruh secara simultan usia, tingkat pendidikan, dan pendapatan usaha terhadap tingkat literasi keuangan. Hasil penelitian ini menunjukkan bahwa faktor demografi dan sosio ekonomi memiliki peranan dalam membentuk literasi keuangan.

Faktor demografi akan bisa menjelaskan kondisi dan perubahan masyarakat. Status sosial ekonomi akan berdampak pada perbedaan persepsi atas objek perilaku yang pada akhirnya akan membentuk sikap yang berbeda. Seseorang yang memiliki persepsi mengenai pengetahuan keuangan dalam menjalani usaha akan membentuk sikap positif. Salah satu sikap tersebut adalah dengan berusaha selalu mengikuti perkembangan informasi mengenai keuangan dan bisnis. Hal ini akan berdampak pada peningkatan literasi keuangan yang dimilikinya.

\section{b. Pengaruh Usia terhadap Literasi Keuangan Pelaku UMKM di Kota Bandung}

Berdasarkan hasil penelitian, ditemukan bahwa tidak terdapat pengaruh usia terhadap literasi keuangan secara parsial. Hal tersebut menunjukkan bahwa pertambahan usia tidak mempengaruhi literasi keuangan.

\section{Tabel 5. Literasi Keuangan Berdasarkan} Usia

\begin{tabular}{|c|c|c|c|c|c|}
\hline \multirow[b]{2}{*}{ Usia } & \multicolumn{4}{|c|}{ Skor Rata-Rata } & \multirow{2}{*}{$\begin{array}{c}\text { Skor Rata2 } \\
\text { Literasi } \\
\text { Keuangan }\end{array}$} \\
\hline & $\begin{array}{c}\text { Pengetahuan } \\
\text { Umum Keuangan }\end{array}$ & $\begin{array}{c}\text { Tabungan } \\
\text { dan Hutang }\end{array}$ & Asuransi & Investasi & \\
\hline$\leq \mathbf{2 0}$ & 0.7500 & 1 & 0.5000 & 0.5000 & 0.6875 \\
\hline $21-30$ & 0.7500 & 0.7500 & 0.5000 & 0.3333 & 0.5833 \\
\hline $31-40$ & 0.6875 & 0.7188 & 0.6563 & 0.3125 & 0.5938 \\
\hline $41-50$ & 0.7778 & 0.5556 & 0.5556 & 0.5833 & 0.6181 \\
\hline$>51$ & 0.6667 & 0.6667 & 0.7500 & 0.4167 & 0.6250 \\
\hline
\end{tabular}

Beberapa kelompok usia memiliki ratarata literasi keuangan relatif merata. Perbedaan terjadi hanya pada tingkat usia dibawah 20 tahun dan di atas 51 tahun, tetapi perbedaan tersebut hanya sedikit. Pada usia dibawah 20 tahun biasanya mereka ingin tahu yang lebih besar sehingga terus mencari informasi. Isu-isu keuangan saat ini banyak dipublikasikan pada berbagai bentuk media cetak dan online. Perkembangan teknologi media informasi yang lebih familiar digunakan oleh usia muda juga memudahkan untuk mengakses informasi keuangan secara real time dimanapun berada. Sedangkan pada 
usia di atas 51 tahun karena mereka memiliki pengalaman yang lebih banyak.

Hasil penelitian ini berbeda dengan hasil penelitian yang dilakukan oleh Worthington (2006), Mandell (2008), Ansong \& Gyensare (2012), ANZ (2015), dan OJK (2016).

\section{c. Pengaruh Tingkat Pendidikan}

Terhadap Literasi Keuangan Pelaku

\section{UMKM di Kota Bandung}

Berdasarkan hasil penelitian yang diuji oleh penulis, ditemukan bahwa terdapat pengaruh tingkat pendidikan terhadap literasi keuangan secara parsial. Hal tersebut menunjukkan semakin tinggi tingkat pendidikan formal seseorang akan mempengaruhi literasi keuangannya.

Tabel 6. Literasi Keuangan Berdasarkan Pendidikan Formal

\begin{tabular}{|c|c|c|c|c|c|}
\hline \multirow{2}{*}{$\begin{array}{l}\text { Tingkat } \\
\text { Pendidikan } \\
\text { Formal }\end{array}$} & \multicolumn{4}{|c|}{ Skor Rata-Rata } & \multirow{2}{*}{$\begin{array}{c}\text { Skor Rata2 } \\
\text { Literasi } \\
\text { Keuangan }\end{array}$} \\
\hline & $\begin{array}{c}\text { Pengetahuan } \\
\text { Umum Keuangan }\end{array}$ & $\begin{array}{c}\text { Tabungan } \\
\text { dan Hutang }\end{array}$ & Asuransi & Investasi & \\
\hline SD & 0 & 0 & 0 & 0 & 0 \\
\hline SMP & 0 & 0 & 0 & 0 & 0 \\
\hline SMA & 0.6250 & 0.6875 & 0.4375 & 0.3750 & 0.5313 \\
\hline Diploma & 0.6923 & 0.6346 & 0.6923 & 0.4038 & 0.6058 \\
\hline Sarjana & 0.8611 & 0.7222 & 0.6389 & 0.5000 & 0.6806 \\
\hline
\end{tabular}

Hasil penelitian pada Tabel 6 ini menunjukkan bahwa terjadi peningkatan pengetahuan umum keuangan seiring dengan peningkatan tingkat pendidikan. Hal ini dikarenakan pelaku UMKM yang memiliki tingkat pendidikan lebih tinggi akan lebih familiar dengan istilah ekonomi dan memiliki pemahaman akan isu keuangan secara umum yang lebih baik.
Tingkat literasi keuangan dimensi tabungan dan hutang paling tinggi berada pada responden dengan pendidikan sarjana. Hal ini terjadi karena ketika menjalani pendidikan di perguruan tinggi, mereka sudah akan berhubungan langsung dengan produk perbankan. Ada tuntutan untuk mengenal produk perbankan agar tidak terjadi penyalahgunaan. Hal ini mungkin tidak terjadi pada responden yang setelah menyelesaikan pendidikan setingkat SMA langsung terjun ke dunia bisnis. Biasanya mereka tidak akan langsung berurusan dengan keuangan, namun lebih ke hal produksi atau relasi.

Tren positif juga ditunjukkan pada dimensi asuransi dan investasi. Lingkungan pendidikan jenjang tinggi akan membiasakan seseorang memiliki tahapan perencanaan akan hal yang dilakukannya, begitu juga dengan penggunaan keuangan. Asuransi sebagai proteksi dan investasi sebagai sumber pendapatan alternatif adalah bagian dari perencaan penggunaan produk keuangan. Hal tersebut mendorong seseorang untuk mencari informasi sebanyak-banyaknya mengenai asuransi dan investasi sebagai bagian dari perencanaan keuangan.

Tingkat pendidikan adalah sistem pendidikan yang terorganisir dimana struktur dan administrasinya mengikuti aturan hukum sebagai kurikulum yang baku. Hasil 
penelitian ini menunjukkan bahwa tingkat pendidikan memiliki peranan paling besar sebagai faktor yang mempengaruhi literasi keuangan. Tingkat literasi keuangan yang lebih tinggi pada pelaku UMKM yang memiliki pendidikan tingkat tinggi dikarenakan ilmu pengetahuan mengenai ekonomi yang didapat lebih banyak saat perkuliahan. Meskipun saat pendidikan menengah juga mendapatkan pendidikan ekonomi, namun ilmu yang didapat tidak terlalu rinci. Tingkat pendidikan mempengaruhi literasi keuangan karena semakin tinggi tingkat pendidikan yang ditempuh, maka seseorang akan memiliki pemahaman dan wawasan yang luas dalam mengelola sumber pendapatannya Dengan pendidikan yang lebih tinggi, seseorang akan lebih familiar dengan istilah-istilah ekonomi yang secara tidak langsung juga akan mempengaruhi literasi keuangan.

Semakin tinggi pendidikan formal seseorang, biasanya orang tersebut akan memiliki sikap yang lebih kritis dan selektif dalam memilih produk keuangan. Sikap tersebut muncul karena lingkungan pendidikan yang menuntut seseorang untuk sebisa mungkin kritis dan peka terhadap fenomena yang terjadi. Seseorang dengan sikap kritis akan memikirkan keuntungan dan risiko terhadap hal yang dilakukannya. Untuk menghindari risiko, akan dicari informasi selengkap-lengkapnya mengenai produk keuangan yang akan digunakan. Kebiasaan mencari informasi dan pola pikir kritis tersebut yang secara tidak langsung berpengaruh pada peningkatan literasi keuangan.

Hasil di atas menunjukkan hasil yang sesuai dengan penelitian yang dilakukan oleh Worthington (2006), Ansong \& Gyensare (2012), Suachi (2013), Mahdzan dan Tabiani (2013), ANZ (2015) dan OJK (2016) yang menyatakan bahwa tingkat pendidikan berpengaruh positif terhadap literasi keuangan..

\section{d. Pengaruh Pendapatan Usaha Terhadap}

Literasi Keuangan Pelaku UMKM di

\section{Kota Bandung}

Berdasarkan hasil penelitian yang diuji oleh penulis, ditemukan bahwa terdapat pengaruh pendapatan usaha terhadap literasi keuangan secara parsial.

\section{Tabel 7. Literasi Keuangan Berdasarkan}

\section{Pendapatan Usaha}

Hasil penelitian pada Tabel 7 menunjukan adanya kecenderungan tren positif literasi keuangan dimensi tabungan dan hutang sejalan dengan peningkatan pendapatan usaha. Pendapatan usaha yang tinggi akan mendorong peningkatan penggunaan produk perbankan. Selain meningkatkan pengetahuan mengenai produk 
perbankan itu sendiri, pelaku usaha juga akan mengetahui tentang arus kas dari usaha yang dijalani. Hal tersebut secara tidak langsung juga akan mempengaruhi pengetahuan keuangan umum dari pelaku usaha.

Semakin besar pendapatan usaha, pelaku usaha akan memiliki cadangan dana yang lebih besar. Apabila tidak digunakan untuk pengembangan usaha utama, dana tersebut dapat dimanfaatkan untuk mendapat penghasilan tambahan, salah satunya melalui penggunaan produk investasi. Maraknya investasi bodong mengharuskan pelaku usaha yang memiliki minat untuk berinvestasi untuk mencari informasi mengenai investasi agar tidak menjadi korban penipuan. Adanya pencarian informasi agar investasi yang dipilih tepat dan sesuai akan meningkatkan literasi keuangan dimensi investasi pada pelaku usaha.

Pendapatan merupakan inflow of assets akibat penjualan barang dan/atau jasa ke dalam perusahaan. Pada penelitian ini pendapatan usaha diukur melalui pendapatan rata-rata per bulan dalam satuan jutaan rupiah. Pelaku UMKM yang memiliki pendapatan usaha lebih tinggi akan cenderung memiliki literasi keuangan yang lebih tinggi. Orang yang memiliki tingkat pendapatan usaha lebih tinggi akan cenderung memiliki kemampuan untuk merencakan dan mengontrol keuangannya dengan baik. Hal ini dikarenakan dengan semakin tingginya pendapatan usaha, akan semakin banyak aset yang harus dikelola oleh pelaku UMKM. Semakin tinggi pendapatan seseorang, maka orang tersebut akan berusaha mencari informasi dan pemahaman untuk memanfaatkan uang yang dimilikinya. Pendapatan yang lebih tinggi menunjukkan kesempatan yang lebih besar kepada seseorang untuk lebih bertanggung jawab terkait dengan ketersediaan dana yang dimilikinya.

Hasil penelitian ini sejalan dengan hasil penelitian Worthington (2006), Andrew \& Linawati (2014), ANZ (2015) dan OJK (2016) yang menyatakan tingkat pendapatan berpengaruh positif terhadap literasi keuangan.

\section{Kesimpulan}

Berdasarkan hasil penelitian dan pembahasan, maka dapat diambil kesimpulan sebagai berikut.

1) Terdapat pengaruh usia, tingkat pendidikan, dan pendapatan usaha secara simultan terhadap literasi keuangan pelaku UMKM di Kota Bandung.

2) Tidak terdapat pengaruh usia terhadap tingkat literasi keuangan pelaku UMKM di Kota Bandung. Hal ini menunjukkan bahwa perbedaa usia tidak mempengaruhi literasi keuangan.. 
3) Terdapat pengaruh tingkat pendidikan terhadap literasi keuangan pelaku UMKM di Kota Bandung. Hal ini menunjukkan bahwa bila semakin tinggi pendidikan seseorang, maka literasi keuangannya juga akan mengalami peningkatan.

4) Terdapat pengaruh pendapatan usaha terhadap literasi keuangan pelaku UMKM di Kota Bandung. Hal ini menunjukkan bahwa bila semakin tinggi pendapatann usaha, maka literasi keuangannya juga akan mengalami peningkatan

\section{DAFTAR PUSTAKA}

Andrew, Vincentius \& Nanik Linawati. 2014. Hubungan Faktor Demografi dan Pengetahuan Keuangan Dengan Perilaku Keuangan Karyawan Swasta di Surabaya. FINESTA Vol. 02, No. 02, (2014) 35-39

Anggraeni, Birawani Dwi. 2015. Pengaruh Tingkat Literasi Keuangan Pemilik Usaha Terhadap Pengelolaan Keuangan, Studi Kasus pada UMKM Depok. Journal of Vocational Program University of Indonesia, Vol.3, No.1.

Ansong, A. and Gyensare, M. A.. 2012. Determinants of University WorkingStudents' Financial Literacy at the University of Cape Coast, Ghana. International Journal of Business and Management, Volume 7 No. 9. Hal 126-133.

ANZ. 2015. ANZ Survey of Adult Financial Literacy in Australia. Melbourne: ANZ Bank and AC Nielsen.

Ayu Krishna, Rofi Rofaida, dan Maya Sari, 2010. Analisis Tingkat Literasi Keuangan di Kalangan Mahasiswa dan Faktor-Faktor yang Mempengaruhinya (Survey Pada Mahasiswa Universitas
Pendidikan Indonesia). Proceedings of The $4^{\text {th }}$ International Conference on Teacher Education.

Chen, H., \& Volpe, R.P. (1998). An analysis of personal financial literacy among college students. Financial Services Review, 7, 107.

Cude, B. J, Lawrence, F. C, Lyons, A. C, Metzger, K, LeJeune, E, Marks, L. \& Machtmes, K. 2006. College Students and Financial Literacy: What They Know and What We Need to Learn. Eastern Family Economics and Resource Management Association2006 Conference

Gupta, Kamal \& Jatinder Kaur. 2014. A Study of Financial Literacy Among Micro Entrepreneurs in District Kangra. Impact Journals, Vol.2, Issue 2, 63-70.

Hapsari, E. I. 2012. Kekuatan Rasio Keuangan dalam Memprediksi Kondisi Financial Distress Perusahaan Manufaktur di BEI. Jurnal Dinamika Manajemen. 3 (2)

Hilgert, M. A., Hogarth, J. M., \& Beverly, S. G. (2003). Household financial management: The connection between knowledge and behavior. Federal Reserve Bulletin, 309-322

Kardinal. 2015. Kontribusi Literasi Keuangan terhadap Penggunaan Produk Keuangan pada Masyarakat Indonesia. Proceeding Sriwijaya Economic and Busimess Conference 2015, Hal. 574-589. Palembang: Universitas Negeri Sriwajaya.

Kharchenko, Olga. 2011. Financial Literacy in Ukraine : Determinants and Implication for Saving Behaviour. Ukraine : Kyiv School of Economic.

Lusardi, A., \& Mitchelli, O. 2007. Financial Literacy and Retirement Preparedness: Evidence and Implications for Financial Education. Business Economics, 42, 35.

Mahdzan, N.S., Tabiani, S. 2013. The Impact of Financial Literacy on Individual Saving: an Explatoratory Study in the Malaysia Context. Transformations in 
Business \& Economics, Vol. 12, No 1 (28), pp.41-55.

Mandell, Lewis. 2008. The Financial Literacy of Young American Adults: Results of The 2008 National Jump\$Tart Coalition Survey of High School Seniors and College Student. Washington, DC: The Jump\$Tart Coalition for Personal Financial Literacy

Mendari, Anastasia Sri dan Suramaya Suci Kewal. 2014. Tingkat Literasi Keuangan di Kalangan Mahasiswa STIE MUSI. Hal. 130-140.

Nababan, Darman, Isfenti Sadalia. 2013. Analisis Personal Financial literacy dan Financial behavior Mahasiswa Strata I Fakultas Ekonomi Universitas Sumatera Utara. Jurnal Universitas Sumatera Utara. Vol.1, No.1. pp. 1-16.

Otoritas Jasa Keuangan, 2016. Peraturan Otoritas Jasa Keuangan Tahun 2016 tentang Peningkatan Literasi dan Inklusi Keuangan di Sektor Jasa Keuangan Bagi Konsumen dan/atau Masyarakat. Jakarta: Kementerian Hukum dan HAM Republik Indonesia.

Orton, Larry. 2007. Financial Literacy: Lessons from International Experience. CPRN Research Report September 2007. Ontario: Canadian Policy Research Networks Inc.

Oseifuah, Emmanuel Kojo. 2010. Financial Literacy and Youth Entrepreneurship in South Africa. Thohoyandou: Department of Accounting and Auditing University of Venda.

Riski Amaliyah \& Rini Setyo Witiastuti. 2015. Analisis Faktor yang Mempengaruhi Tingkat Keuangan di Kalangan UMKM Kota Tegal. Management Analysis Journal 4 (3) Universitas Negeri Semarang.

Sari, Henny Rachma Sari. 2014. Jumlah UMKM Indonesia 57,9 juta, Terbanyak di Banding Negara Lain pada https://www.merdeka.com/uang/jumlahumkm-indonesia-579-juta-terbanyak- dibanding-negara-lain.html diakses pada 9 Januari 2017.

Sucuachi, William T. 2013. Determinants of Financial Literacy of Micro Entrepreneurs In Davao City. International Journal of Accounting Research Vol. 1, No.1.

Widayati, Irin. 2012. Faktor-Faktor yang Mempengaruhi Literasi Finansial Mahasiswa Fakultas Ekonomi dan Bisnis Universitas Brawijaya. Jurnal Akuntansi dan Pendidikan, Volume 1. No. 1. Hal. 89-99.

Wise, Sean. 2013. The Impact of Financial Literacy on New Venture Survival. International Journal of Business and Management, Volume 8, No. 23

Worthington, Andrew C. 2006. Predicting financial literacy in Australia. Financial Services Review, 15(1), 59-7.

Yuliana, V. 2013. Analisis Pengaruh Variabel Keuangan Dan Non Keuangan Terhadap Initial Return dan Return Setelah IPO. Management Analysis Journal. 2(2) 